\title{
Рецензия на учебное пособие д.ю.н., профессора Ковалева А.А. «Международное экономическое право и правовое регулирование международной экономической деятельности на современном этапе»
}

\section{Богатырев А.Г. ${ }^{*}$}

В основу очередного учебного пособия проф. Ковалева А.А. положен курс его лекций по проблемам международного экономического права на протяжении последних 14 лет в Дипломатической Академии Министерства иностранных дел Российской Федерации.

Представленное учебное пособие по основным идеям, направленности и содержанию носит самостоятельный характер, является авторским.

Рецензируемое учебное пособие представляет собой исследование отраслевых принципов международного экономического права, его основных подотраслей и роли международных экономических организаций в условиях глобализации.

В связи с большим влиянием на международные экономические отношения интеграции государств в экономической сфере, в учебном пособии достаточно подробно рассмотрены правовые вопросы международной экономической интеграции в рамках Европейского Союза, ЕврАзЭС и других интеграционных объединений, представляющих особый интерес для России.

В учебном пособии А.А. Ковалева нашли отражение также и такие важные для современных экономических отношений вопросы как международно-правовое регулирование иностранных инвестиций, источники международного инвестиционного права и вопросы осуществления иностранных инвестиций в российскую экономику.

Учитывая, что при всей своей самодостаточности современная российская экономика едва ли может эффективно развиваться без активного взаимодействия с мировым рынком товаров, услуг и капиталов, большое место в пособии уделяется правовым вопросам создания и деятельности Всемирной торговой организации, вопросам присоединения

* Богатырев А.Г. - профессор кафедры международного права Российской академии правосудия. 
России к этой универсальной организации, регулирующей международные отношения в сфере торговли товарами, услугами, продукцией интеллектуальной собственности.

Следует признать в высшей степени положительным то, что в исследовании проблем международного экономического права автор исходит из основных положений общей теории права, которые успешно им применяются при рассмотрении вопросов создания и структуры международного экономического права, его субъектов, источников и специальных (отраслевых) принципов.

Несомненным достоинством рецензируемого учебного пособия является то, что изложение теоретических аспектов международного экономического права сочетается с анализом практически важных и наиболее актуальных международно-правовых проблем международных экономических отношений.

Исходя из того, что государство является основным субъектом международного экономического права, А.А. Ковалев рассматривает иммунитет государства как выражение национального суверенитета, а также юрисдикционный иммунитет, иммунитет от предварительного обеспечения иска и иммунитет от принудительного исполнения судебного (арбитражного) решения, универсально применимые в международных отношениях государств. Все эти вопросы имеют исключительно важное значение для российских юридических лиц и судебных органов, неоднократно сталкивающихся с ними на практике.

Значительный вклад в развитие теории международного экономического права вносит глубокое исследование автором особенностей международной правосубъектности государств, международных организаций и других субъектов внешнеэкономической деятельности (ТНК, международные хозяйственные организации, физические лица).

В связи с усложнением отношений, регулируемых международным экономическим правом, увеличением объема нормативного и фактологического материала, необходимостью его систематизации и упорядоченного применения, трудно переоценить значение учебного пособия А.А. Ковалева. В нем изложены данные и факты, которые могут в большей или меньшей степени известны читателям, на которых рассчитано рецензируемое пособие. Однако освещение этих данных и фактов может помочь более четкому представлению сущности современных проблем правового регулирования международной экономической деятельности. 
Автор пособия ненавязчиво привлекает внимание слушателей, студентов, иных читателей к важности понимания специальных юридических вопросов международного экономического права, справедливо опираясь на уже имеющиеся у читателя знания по общему курсу международного права. В этом ценность пособия: оно ориентирует на углубление знаний в такой отрасли международного права, какой является международное экономическое право. 